\title{
Migration processes as a factor of labor market regulation
}

\author{
Vladimir Polovinko ${ }^{\mathrm{a}, \mathrm{b}}$, Anna Arbuz ${ }^{\mathrm{a}, \mathrm{b}^{*}}$ \\ ${ }^{a}$ Department of Economics and human resource management \\ b"Omsk State University n. a. F. M. Dostoevsky", Russia \\ Corresponding author: Anna Arbuz, denezhkina1@mail.ru
}

\begin{abstract}
This study examines the trends of migration processes in Omsk region related to the increase in the outflow of the indigenous population, including young representatives, as a rule, well-educated.These developments of situation will contribute to increasing disparities at the regional labor market, the degradation of the education system, professional associations, and many other problems. The author explores the migration of the population of the Omsk region in the context of employment and development trends of the regional labor market. As a result, the author comes to the conclusion that the data migration intentions of the population to leave the region associated with dissatisfaction with the state of the local labor market, namely low wages, limited opportunities to find a job and build a career in home region.
\end{abstract}

Key words: migration processes; employment; labor market; migration expectations

\section{Introduction}

Labor migration as a social phenomenon is influenced by existing labor market conditions and the market economy. The economic and social factors determine to a greater extent migration processes in the country. Thus, the implementation of the exam, the consolidation of universities, the establishment of large Federal and research universities, and so forth leads to the fact that many graduates are choosing large central universities, leaving their region. In addition, a significant enough trend to strengthen the role of large corporations and holding companies with headquarters in big cities of Russia (Moscow, Saint-Petersburg, Yekaterinburg, Novosibirsk, etc.). In these organizations, attractive working conditions and staff development, which in turn attracts highly qualified human resources from the regions of Russia, in particular from the Omsk region are created.

Labor migration represents a twofold process: on the one hand it is an essential element in the functioning of the labor market and it affects the redistribution of labor resources in the 
country, but on the other hand too high labor migration of causes of the problem of staff turnover. Consequently, the management of labor migration is one of the major issues of labor economics.

\section{Experimental}

Issues of migration and labor market is discussed by E. Nemeryuk, L. Anikina, N.Volgin, G. Odegova, V. Polovinko, J. Florinski, N. Mkrtchyan, T. Maleva, S. Anofrikov ${ }^{1-5}$ and others. The regional aspect of migration studies is presented in the works of O. Rybakovsky ${ }^{6}$ and others. In foreign literature is presented experience of international youth (student) migration (Chen, Barnett) ${ }^{7}$, centre and periphery, in terms of migration flows (Barnett, Wu) ${ }^{8}$, psychological aspects of interaction between host and losing the region's population (Findlay) ${ }^{9}$.

The purpose of this article is to review contemporary trends of migration processes in the context of employment of the population of Omsk region and regional labor market. As the main hypothesis was the assumption that the currently most relevant aspects of migration are the trends out the local population of Omsk region, which, in turn, are associated with the lack of an effective mechanism of regulation of population migration.

\section{Results and discussion}

The analysis of the demographic situation in Omsk region allowed to reveal the trends of downsizing and the aging of the population, growth of demographic burden on the working population, the development of migration processes. In 2014-2016 it is possible to ascertain the decrease in the number of persons of working age table 1.

Table 1 - Dynamics of population in Omsk region depending on age, thousand people

\begin{tabular}{|l|c|c|c|c|}
\hline The population depending on age, thousand & \multicolumn{4}{|c|}{ Year (1 January) } \\
\cline { 2 - 5 } people & 2013 & 2014 & 2015 & 2017 \\
\hline The population of working age & 1177,9 & 1159,8 & 1136,8 & 1113,2 \\
\hline The population younger than working age & 349 & 359,8 & 371,1 & 378,9 \\
\hline The population over working age & 446,9 & 458,6 & 470,5 & 480,5 \\
\hline
\end{tabular}

In 2014-2016, the annual loss of population in working age on average is about 20 thousand people.

Given the forecasts for the years 2016-2020, the number of this part of the population of the Omsk region will decrease by almost 100 thousand (8\%), population over working age will increase by 80 thousand people (18\%). 
Also, the increase of the dependency ratio on the working population, it should be noted. Thus, according to the 1 January 2016 data, there was 379 people on 1 thousand people over working age , as to the 1 January 2017 data, there was 431 of working age on 1 thousand people. Given the forecasts, by 2020, in Omsk region this indicator will amount to 484 persons over working age per 1 thousand people of working age ${ }^{10}$.

Examining the main demographic trends of formation of labor resources of the Omsk region, it can be concluded that the outflow of working age population does not compensate for the occurrence in this age group of youth. It is therefore necessary to increase the use of already formed labor potential of Omsk region, the strengthening of measures aimed at the preservation and development of human resources, involving citizens from other regions and countries.

The development of migration processes on the territory of Omsk region, characterized by a migratory population decline. So, for the first six months of 2017, this figure amounted to 5215 people for 2016 - 5942 person in 2015 1,800 people ${ }^{11}$. Thus, we can state the trend associated with the population outflow from the region. If all this is to explore in the context of declining working-age population, we can understand that Omsk oblast expect serious problems on the regional labor market, which will certainly affect the socio-economic development of the region as a whole.

In Omsk region, as we have noted, in recent years there is a negative situation, related to the outflow of population. The fact migration intention to leave is worrying the region. Our previous studies revealed that the migration attitudes of the population had been to great extend associated with poor living conditions. The problem is that local government is not willing to see this situation, or does not associate it with socio-economic and administrative, as it was identified, factors ${ }^{12-13}$.

So, in 2016 we together with "Gepitcentre-2" within the project "SibMONITOR" conducted in 2016, a study aimed at examining the migration attitudes of the population of Omsk region. This is a quarterly survey of the population of Omsk region and Omsk city 18 years and older for a representative sample, representing all economic zones (areas) of the Omsk region.

The number of sample amounted to 2445 respondents. The sample of respondents formed on the basis of the combined three-stage sampling using allocation procedures and the method of randomly sampling without replacement selection of respondents to the routes to their places of residence on the territory of the regional centre and municipal districts of Omsk region. In 2017, the second study was conducted in a similar way. 
Results show the identified trend associated with the formation of a steady migration of plants from residents of Omsk region. Thus, the number of people made the decision to leave and taken active steps from $7.1 \%$ in 2016 to $8.5 \%$ in 2017 has increased. Also,the number of people intending to leave Omsk, but so far has reason from $17.7 \%$ to $21.2 \%$ (table 2).

Table 2 - Distribution of respondents ' answers to the question "Have you ever thought about how to move from Omsk in the other place?" in \% to number of respondents, $\mathrm{N}=2445$

\begin{tabular}{|l|c|c|}
\hline Migration & \multicolumn{2}{|c|}{ Year } \\
\cline { 2 - 3 } & 2016 & 2017 \\
\hline Sometimes I think about moving & 36,4 & 33,1 \\
\hline I don't want and are not going to move & 24,9 & 25,8 \\
\hline I'm Going to move, but yet did nothing & 17,7 & 21,2 \\
\hline Would like to leave on time & 13,9 & 9 \\
\hline Just decided to leave and take active steps & 7,1 & 8,5 \\
\hline Never thought about it & 0 & 2,4 \\
\hline
\end{tabular}

Table 3 - Distribution of answers to the question "If You want to relocate, then what is the reason?" by gender, in \% to number of respondents, $\mathrm{n}=918$

\begin{tabular}{|l|l|l|}
\hline \multirow{2}{*}{ The reasons for changing place of residence } & Gender \\
\cline { 2 - 3 } Many of my friends went from Omsk, Omsk region & Male & Female \\
\hline In the Omsk region high prices & 14,1 & 20,2 \\
\hline In the Omsk region poor living conditions & 18,6 & 17,8 \\
\hline In the Omsk region bad weather conditions & 49,2 & 54,3 \\
\hline In the Omsk region are few opportunities to find a job & 7,9 & 5,4 \\
\hline $\begin{array}{l}\text { In the Omsk region few opportunities to get a good education to me, my } \\
\text { children }\end{array}$ & 49,7 & 51,9 \\
\hline My relatives want me to leave Omsk region & 10,7 & 7,8 \\
\hline In the Omsk region underdeveloped transport and social infrastructure & 6,2 & 1,6 \\
\hline In the Omsk region low wages & 48,6 & 6,2 \\
\hline Not satisfied with the policy of management of the region & 7,9 & 7,8 \\
\hline In the Omsk region limited opportunities to build a career & 12,4 & 12,4 \\
\hline Another reason & 0,6 & 3,1 \\
\hline
\end{tabular}

Identified new trends and factors of migration processes are not taken into account in strategies and programmes of socio-economic development of the region. These factors primarily include socio-economic, organizational and managerial ones, which was confirmed by the results of our study. We revealed a statistically significant relationship between the 
dissatisfaction with living in Omsk and conditions for life in it. After all, we have found out deterioration in living conditions in the city over the past five years, while youth are concerned about the state of roads and pavements, cleanliness, policy management, city services, utilities, public transport and more. In our view high migration are associated with these factors ${ }^{13}$.

If we talk about the main reasons of migration intentions, citizens of Omsk are not satisfied of the situation of labor market. So, $49,7 \%$ of respondents said that in Omsk region, few opportunities for good employment; 49, 2 \% said poor living conditions; 48.6 percent said low wages in the region (table 3).

As a result of migration there is a "washout" of qualified personnel (often leaving it the most successful and motivated representatives of the region), that will certainly lead to the aggravation of already existing problems on the regional labor market.

\section{Conclusions}

So, in this article we have analyzed migration processes in Omsk region in the context of regional labor market and employment. It has been proven that relevance is the tendency of strengthening of the departure of the local population from the region. The study revealed that migration of the population to leave the region associated with dissatisfaction with the state of the labor market, i.e. low wages, limited opportunities to find a job and build a career in home region. However, the results of the study showed that people planning to leave Omsk region quite carefully plan this event, studying the labor market of the region in which they are planning to go studying his condition through various information sources.

Therefore, the existing model of migration management in the region does not reflect the new trends. It doesn`t contain science-based principles and priorities in their regulation needs to be adjusted. Based on projections of population dynamics, including population projections of working age, priority in the area of migration at present is to contain the migration outflow of the population.

\section{Acknowledgements}

The research is carried out with the financial support of Russian Foundation for Humanities №16-12-55013 


\section{References:}

1. Nemeryuk E., L. Anikin Formation of regional labor market and the factors influencing its development // Herald of Saratov University, 2007, vol. 7, Ser. Sociology. Political science, vol. 1. - Str. 23-29.

2. Volgin N. A. Odegov Y. G. labor Economics. Examination Publ, Moscow (2003) 215.

3. Polovinko $\mathrm{V}$. Regional experience of management of migration processes in Russia // Herald of Omsk University, Ser. Economics, 2017, vol. 1. - Str. 197-205.

4. Florinskaya Y. F., Mkrtchyan N. In. Maleva T. M., Kirillova M. K. Migration and the labour market /Series "Scientific reports: social policy", Delo Ranepa Publ., Moscow, (2015) 54.

5. Anofrikov S. P. the Influence of migration on the labour market of the Novosibirsk oblast // news of Tomsk Polytechnic University 6 (2013) 41-48.

6. Rybakovsky L. L. Demographic challenges: what awaits Russia? // Sociological researches 8 (2012) 12-22.

7. Chen T. and Barnett G.A. Research on International Student Flows from a Macro Perspective: A Network Analysis of 1985, 1989 and 1995 // Higher Education 6 (2000) 435-453.

8. Barnett G.A. and Wu. R.Y. The International Student Exchange Network: 1970 \& 1989// Higher Education, 1995, Vol. 30. - Str. 353-368.

9. Findlay A. From brain exchange to brain gain: Policy implications for the UK of recent trends in skilled migration from developing countries. International Migration Papers No. 43. Geneva, 2002.

10. URL: http: // regionz.ru (10.08.2017)

11. URL:http://omsk.gks.ru/wps/wcm/connect/rosstat_ts/omsk/resources/4105d10041ff5a 128f15ff27f9898572/edn_2016.htm (15.08.2017)

12. Arbuz A. Migration of graduates of Omsk // Herald of Omsk University. Series Economics, 2016, vol. 6. - Str. 139-147.

13. Arbuz A., Ivanov D. Migration intentions of young professionals in Omsk region in the context of labor market relationships. The 10th International Days of Statistics and Economics: Conference Proceedings (September 8-10, 2016) / University of Economics, Prague; ed. by T. Loster, T. Pavelka. - Prague, Czech Republic: LibušeMacáková, Melendrium, (2016) 30-39. 